\title{
The governance at the youth centers as an entrance to the community development in the Arab Republic of Egypt
}

\section{'Dr / Nermeen Ahmad Kamal}

\section{Summary:}

The current study aims to recognize the applicability of the governance principles on the administrative systems which applied inside the youth centers in Egypt, and the influence range of these principles on reaching its aims. The researcher used the descriptive method of the survey method as it suites the research nature. The research community included the elected board of directors, the activities managers and supervisors and sports activity administrators at the villages and cities youth centers in Tanta governorate which numbers of 6 town youth centers, and 205 village youth centers with a total of 211 youth centers. (50) youth centers have been chosen randomly as a basic sample included (4) town youth centers (46) village youth centers, also (5) other youth centers have been chosen as an exploration sample of survey questionnaire procedures, and the study conclusions refer to the following:

- There is a clear failure in applying the principle of transparency inside the youth centers in The Arab Republic of Egypt.

- There is a clear and severe inability in applying the principle of accountability as one of the governance principles inside the youth centers in The Arab Republic of Egypt.

- The existence of a clear inability in applying the participating principle inside the youth centers in The Arab Republic of Egypt.

- An insufficiency in a number of legal and legislative aspects that related with the administrative performance of the youth centers.

The key words: the community development - the governance- The youth centers

\section{The introduction and the research problem:}

In the shadow of the global trends toward the free market and the modern administrative systems it is imperative for the institutions whether they are governmental or civil, seeking for benefits or not to but in consideration the most important pillars that related with the quality of the administrative performance of the institution through applying the integrity, governance and transparency principles which consider the basic guarantee of the institution's ability range to achieve its goals . As without these governor principles, the institution slides down into the administrative and financial corruption which forbidding it to accomplish its duty. The sports institutions aren't isolated of this as they are in a bad need to apply the governance principles to guarantee achieving the goals which it had been built for it. (3) (6)

And the governance is the system which through it the organization can be directed and managed, and it is the process of making and carrying out the decisions, and the nature of governance the organization influencing the method of determining its goals, the method of the board of directors work and observing the performance and the relation of these administrative boards with all of the interested parties and the

beneficiaries of the organization's work, as the good governance doesn't mean only making and applying the roles but it also seeks to develop the organization's performance through good planning and continuous observation to its trajectory, and the god governance characterized of the transparency, accountability, democracy and justice.(2)(7)(9)

\footnotetext{
${ }^{1}$ A teacher at the sports entertainment and management section at the faculty of Physical Education - Tanta University.
} 
The concept of applying the governance standers appears in a number of criterions and determinates which clears in the performance and transparency through presenting a true images of all what happens, and disclosure about what related with the management affairs such as the real financial sources, evaluating the boards of directors and the executive management work and the justify of participating the relations owners in making the decisions according to the participation principle which allows the all to contribute all in its position and specialty in a frame of cooperation and integration ensuring all the parties and the stakeholders rights.(1)(11)

The youth centers represents a youth organizations which directly subject to the management of the ministry of sports and youth and it aims to present an equal chances to the sports practices of the youth from different ages and sexes, on the level of entertainment and championship to create a youth generation which has a physical and physiological well-being that qualifies them to achieve his community development. The role of the youth centers in the Arab Republic of Egypt doesn't limited on expanding the sports practicing area but it extending it to present an integrated package of the sports, cultural, social and arts activities that enhancing the youths' life and ensuring qualifying them to lead the community development train in Egypt through consolidating their spiritual and ethical values and achieving the

balanced mental and physical growth for them to keep them away from the moral aberration and the intellectual and ideological extremism, and so the youth centers play an important role in raising the youth generations by the good cooperation between them and all of the community institutions such as schools and universities to guarantee preparing a generation qualified to the responsibility of leading its country toward a promising future, besides it is one of the most important tools which used by the country to accomplish a complete and continues community development inside the middle and limited income layers in Egypt.(5) And as the other institutions, the youth centers are facing some problems in providing the needed finance to enhance the local community services, also they suffer from a clear weakness in the administrative qualities that draw the future image that the institution follow to achieve the aims the have been previously determined as direct result of aging the administrative practices in force at the youth centers that it doesn't keep up with the social, political and economic changes that Egypt and the world witness through the last two decades of the twenty century and the first decade of the twenty one century, which emerging the need to a special work mechanism starts with applying the governance in the youth centers, emerging the ability of the participation administrative between different parties, attracting the supporters, understanding the work pattern of these youth centers, enhancing effectively in developing the performance which considers the basic of activating the governance concept that depends on putting the roles and standers that determines the relation between the board of directors and the executive administrative from one side and the trainers and members from the other side.(3)(5)(12)

And in order for the youth centers to ensure achieving the planed aims and keeping up with its social and developmental responsibility it needs to seek applying a group of internal and external mechanisms which affect directly on its performance and the abilities of its workers. These mechanisms included the following:

\section{The internal mechanisms:}

- Determining the relation between directors and workers at the youth centers and the board of directors will be the motivators for the internal catalysts for the center governance, as its authority will be following up the administrative performance through:

* The efficiency of the management in the reliable enforcement for the laws and regulations. 
* Following the right financial and accountant roles.

* Carrying out the youth centers aims.

* The decentralization.

- Choosing the executive directors from the experts and qualified members and presenting them a good motivations.

- Tightening the procedure of the disclosure, transparency, punishment and administration.

\section{The external mechanisms:}

And they are supporting and completing the function of the center's internal motivations as it includes:

- Legislations and laws: that the qualification doesn't represents in only putting the laws but also in applying them correctly.

- The reviewing reports: it considers the backbones in activating the governance at the youth centers as it is one of the mechanisms that pushing the center to follow the right roles of the independent periodic inquiry including the whole institution's benefits.

- Replacing the standard of efficiency instead of the traditional upgrading one which depends on the principle of seniority.

- Self- responsibility through feeling the duty and its consequences and what it related with the public affairs instead of exploitation the general resources.(5)

And the researcher sees that doing the youth centers its roles as a true leader in accomplishing the complete and continuous social development and nurturing a generation who is capable on leading this development become a necessary thing to ensure the stability and the luxury of the Egyptian community, and that the youth centers can do this role by developing its administrative performance system and taking all the new methods that can develop the performance of these foundations, which made the researcher do this study to recognize the applicability of the mechanism and the governance principles on the administrative systems the applied inside the youth centers in Egypt and the effectiveness of these principles on motivating these centers to achieve its aims.

\section{The objective of the study:}

The current study aims to recognize the applicability of the mechanism and the governance principles on the administrative systems the applied inside the youth centers in Egypt and the effectiveness of these principles on motivating these centers to achieve its aims and presenting a some recommendations and suggestions through which it is possible to activate the governance policies and restructuring the sports organizations in general and youth centers in particular which ensure achieving its aims and ding its role in the community development.

\section{The study questions:}

The study questions concentrated at the following:

1- What is the characterized features of the governance? And what is the implementations of it at the youth centers?

2- Are the governance applications requirements provided at the sports organizations especially at the youth centers?

3- How the administrative systems can be developed to upgrade the performance level at the youth centers, and its effect on the quality of the final result of these centers?

4- What are the expected results of applying these suggestions on the sports organizations in general and youth centers in particular according to the strategic dimension that characterized it among the sports organizations? 


\section{The study procedures:}

The research methodology:

The researcher used the descriptive method by the survey method as it is relevance of the research nature.

The community and the sample of the research:

The research community included the elected board of directors, the activities mangers and the supervisors and the administrators of the sports activity at the town and villages' youth centers in Tanta governorate with the number of (6) town youth centers and (205) village youth centers with the total of 211 youth centers. And (50) youth centers have been selected randomly as a basic sample included (4) town youth centers and (46) village youth centers that the researcher choose to distribute (6) questionnaire on (3) of the board of directors and the center manager, (1) of the activity supervisor, (1) of the sports activity administrator at all of the youth centers that forms the sample with the total of (300) questionnaire, also 89 questionnaires have been excluded since they have not been completed or not returned to the researcher and by that the total of the sample numbers are (211) of the board of directors, activities managers and supervisors and the sports activity administrators at the youth centers. also (5) of another youth centers have been chosen as an exploratory sample of the questionnaire survey rationing procedures.

The study tool:

The researcher designed the questionnaire of "The governance mechanisms as an entrance of the community development at the youth centers in The Arab Republic Of Egypt" which included (38) sentences distributed on (4) axes. and the researcher has designed the questionnaire used the previous studies that related with the specialist experts at the sports field.

Rationing the questionnaire:

In order to ration the questionnaire the researcher used the following procedures:

First the sincerity:

A-The sincerity of the arbitrators:

The researcher formulated the questionnaire in its initial image also the sentences of each axe and presented it over (10) of the experts of the Egyptian universities faculty members with the sports administrative specializations at the physical education faculties to recognize their opinions about the axes and the phrases of each one to reach to the final image of the questionnaire, and the opinion of the experts was to accept the phrases and the axes that related with it without adjustments.

B- The internal consistency sincerity:

The researcher applied the final image of the questionnaire on the survey sample $(n=30)$ of the board of directors members, the managers, the activity supervisors and sports activity administrative with the number of (5) youth centers in Algharbia governorate to calculate the correlation coefficient between each phrase and its axe according to the table (1).

The correlation coefficient values between each phrase and the total Table (1) summation of each axe

\begin{tabular}{|c|c|c|c|c|c|c|c|}
\hline \multicolumn{2}{|c|}{ The first axis } & \multicolumn{2}{c|}{ The second axis } & \multicolumn{2}{c|}{ The third axis } & \multicolumn{2}{c|}{ The fourth axis } \\
\hline $\begin{array}{c}\text { The } \\
\text { phrase } \\
\text { number }\end{array}$ & $\begin{array}{c}\text { The } \\
\text { correlation } \\
\text { coefficient }\end{array}$ & $\begin{array}{c}\text { The } \\
\text { phrase } \\
\text { number }\end{array}$ & $\begin{array}{c}\text { The } \\
\text { correlation } \\
\text { coefficient }\end{array}$ & $\begin{array}{c}\text { The } \\
\text { phrase } \\
\text { number }\end{array}$ & $\begin{array}{c}\text { The } \\
\text { correlation } \\
\text { coefficient }\end{array}$ & $\begin{array}{c}\text { The } \\
\text { phrase } \\
\text { number }\end{array}$ & $\begin{array}{c}\text { The } \\
\text { correlation } \\
\text { coefficient }\end{array}$ \\
\hline $\mathbf{1}$ & $* \mathbf{0 . 5 0 3}$ & $\mathbf{1}$ & $* \mathbf{0 . 7 0 6}$ & $\mathbf{1}$ & $* \mathbf{0 . 5 7 8}$ & $\mathbf{1}$ & $* \mathbf{0 . 4 3 7}$ \\
\hline $\mathbf{2}$ & $* \mathbf{0 . 6 3 0}$ & $\mathbf{2}$ & $* \mathbf{0 . 7 9 0}$ & $\mathbf{2}$ & $* \mathbf{0 . 4 5 5}$ & $\mathbf{2}$ & $* \mathbf{0 . 5 4 9}$ \\
\hline $\mathbf{3}$ & $* \mathbf{0 . 6 1 1}$ & $\mathbf{3}$ & $* \mathbf{0 . 7 2 2}$ & $\mathbf{3}$ & $* \mathbf{0 . 5 3 1}$ & $\mathbf{3}$ & $* \mathbf{0 . 5 3 1}$ \\
\hline $\mathbf{4}$ & $* \mathbf{0 . 6 2 3}$ & $\mathbf{4}$ & $* \mathbf{0 . 6 1 0}$ & $\mathbf{4}$ & $* \mathbf{0 . 5 1 2}$ & $\mathbf{4}$ & $* \mathbf{0 . 5 9 7}$ \\
\hline $\mathbf{5}$ & $* \mathbf{0 . 4 3 6}$ & $\mathbf{5}$ & $* \mathbf{0 . 4 9 2}$ & $\mathbf{5}$ & $* \mathbf{0 . 6 6 6}$ & $\mathbf{5}$ & $* 0.433$ \\
\hline $\mathbf{6}$ & $* \mathbf{0 . 6 2 4}$ & $\mathbf{6}$ & $* \mathbf{0 . 7 9 3}$ & $\mathbf{6}$ & $* \mathbf{0 . 7 3 0}$ & $\mathbf{6}$ & $* 0.581$ \\
\hline 7 & $* \mathbf{0 . 6 6 0}$ & $\mathbf{7}$ & $* \mathbf{0 . 7 5 0}$ & $\mathbf{7}$ & $* \mathbf{0 . 5 4 9}$ & $\mathbf{7}$ & $* \mathbf{0 . 6 7 0}$ \\
\hline
\end{tabular}




\begin{tabular}{|c|c|c|c|c|c|c|c|}
\hline $\mathbf{8}$ & $* \mathbf{0 . 4 5 1}$ & $\mathbf{8}$ & $* \mathbf{0 . 6 8 7}$ & $\mathbf{8}$ & $* \mathbf{0 . 5 3 1}$ & $\mathbf{8}$ & $* \mathbf{0 . 5 1 2}$ \\
\hline $\mathbf{9}$ & $* \mathbf{0 . 4 3 0}$ & $\mathbf{9}$ & $* \mathbf{0 . 5 4 9}$ & $\mathbf{9}$ & $* \mathbf{0 . 5 9 7}$ & & \\
\hline 10 & $* \mathbf{0 . 6 1 3}$ & $\mathbf{1 0}$ & $* 0.531$ & & & & \\
\hline 11 & $* \mathbf{0 . 4 5 6}$ & & & & & & \\
\hline
\end{tabular}

The tablet $(\mathrm{r})$ value at the level of significance $(0.05)=0.349$

From the table (1) it clears that the Berson correlation coefficient values between the phrases and its axis came with a statistically indication for all of the phrases as the value of the calculated correlation coefficient higher than its tablet values with an indication level of (0.05) that points to the honesty of the questionnaire.

Second the stability:

To check the scale stability the researcher depended on midterm partial that calculate the internal homogeneity of the scale's paragraphs as the researcher calculated with the Alpha correlation for the stability according to the statistical equation of Kuder and Richardson as the Alpha correlation represents the correlation average resulted of fragmentizing the test into parts in different methods, therefore it represents the correlation coefficient between any two parts of the questionnaire and the table (2) clears the stability correlation with the Alpha method.

Table (2) The Alpha correlation values for the questionnaire dimensions

\begin{tabular}{|c|c|c|}
\hline The axis & The axis title & $\begin{array}{c}\text { The Alpha } \\
\text { correlation }\end{array}$ \\
\hline The first axis & $\begin{array}{c}\text { The Transparency at the youth centers as an entrance } \\
\text { of the community development }\end{array}$ & $\mathbf{0 . 8 1 1}$ \\
\hline The second axis & $\begin{array}{c}\text { The liability at the youth centers as an entrance of the } \\
\text { community development }\end{array}$ & $\mathbf{0 . 7 5 3}$ \\
\hline The third axis & $\begin{array}{c}\text { The participation at the youth centers as an entrance } \\
\text { of the community development }\end{array}$ & $\mathbf{0 . 7 6 8}$ \\
\hline ;0uThe fourth axis & $\begin{array}{c}\text { The rule of low at the youth centers as an entrance of } \\
\text { the community development }\end{array}$ & $\mathbf{0 . 8 3 5}$ \\
\hline
\end{tabular}

The $(r)$ value at a the level of significance $(0.05)=0.349$

From the table (2) it clears that the stability correlation values with the Alpha method of the questionnaire dimensions ranged between $(0.753$ and 0.835$)$ and it is its highest value at the significant level (0.05) that indicates the stability of the questionnaire.

The survey study:

The researcher applied the questionnaire- "the governance mechanisms as an entrance to the community development at the youth centers in the Arab Republic of Egypt"- on a sample of (30) members of the board of directors ,managers, activity supervisors and sports activity administrators with the number of (5) youth centers in Alghabia governorate, during the period of $1 / 11 / 2016$ to $19 / 11 / 2016$ to check the scientific correlations of the questionnaire and the survey study resulted that the questionnaire has high stability and sincerity correlations.

The basic application of the questionnaire:

The researcher applied the questionnaire "the governance mechanisms as an entrance to the community development at the youth centers in the Arab Republic of Egypt" on the basic sample $(\mathrm{n}=211)$ during the period $r / / 11 / 2016$ to $9 / 2 / 2017$ through distributing the questionnaire on the youth centers during field visits then recollecting it again.

The statistical treatments:

After finish applying the questionnaire on the basic sample of the study the researcher evacuated the data and treated it statistically by using the SPSS programming and this to calculate: 
the percentage - the repetition- the Berson correlation coefficient - the Alpha stability correlation- the comparatively importance- Ka2.

Representing and discussing the results:

First: representing the results:

Table (3) The percentage, The repetition, The comparatively importance and the first axis phrase's weighting ( the transparency at the youth centers as an entrance to the community development $)(n=211)$

\begin{tabular}{|c|c|c|c|c|c|c|c|c|c|}
\hline \multirow{2}{*}{$\begin{array}{l}\text { The } \\
\text { term } \\
\text { num }\end{array}$} & \multirow{2}{*}{ The first axis phrase } & \multicolumn{2}{|c|}{ Yes } & \multicolumn{2}{|c|}{ Partly } & \multicolumn{2}{|c|}{ No } & \multirow{2}{*}{$\begin{array}{l}\text { Weightin } \\
\mathrm{g}\end{array}$} & \multirow{2}{*}{$\begin{array}{c}\text { The } \\
\text { comparativel } \\
\text { y importance }\end{array}$} \\
\hline & & $\mathbf{K}$ & $\%$ & $\mathbf{K}$ & $\%$ & $\mathbf{K}$ & $\%$ & & \\
\hline 1 & $\begin{array}{l}\text { Lake of the information that related with the } \\
\text { leadership at the youth centers in front of the } \\
\text { workers to clear their commitments and their } \\
\text { rights toward the work make them make a lot of } \\
\text { mistakes }\end{array}$ & 150 & 71.1 & 9 & 4.3 & 52 & 24.6 & 520 & 82.15 \\
\hline 2 & $\begin{array}{l}\text { The inability of some external benefiter owners to } \\
\text { obtain information about the youth centers that } \\
\text { facilitating to deal with these centers. }\end{array}$ & 140 & 66.4 & 50 & 23.7 & 21 & 10.0 & 541 & 85.47 \\
\hline 3 & $\begin{array}{l}\text { The center doesn't appoint an employee according } \\
\text { to the quality principle or the standard that should } \\
\text { be provide in the employees which affect the } \\
\text { performance at the youth centers. }\end{array}$ & 130 & 61.6 & 41 & 19.4 & 40 & 19.0 & 512 & 80.88 \\
\hline 4 & $\begin{array}{l}\text { The shortage of the media sources at the youth } \\
\text { centers to obtain the information the needed to the } \\
\text { community. }\end{array}$ & 110 & 52.1 & 90 & 42.7 & 11 & 5.2 & 521 & 82.31 \\
\hline 5 & $\begin{array}{l}\text { The inability of the administrative system at the } \\
\text { youth centers to attract the best elements to handle } \\
\text { the administrative jobs at these centers. }\end{array}$ & 140 & 66.4 & 35 & 16.6 & 36 & 17.1 & 526 & 83.10 \\
\hline 6 & $\begin{array}{l}\text { The inability of the administrative system at the } \\
\text { youth centers to develop a new mechanism to } \\
\text { enable the community to express its opinion and } \\
\text { suggests toward the youth centers and benefit of } \\
\text { these suggestions }\end{array}$ & 135 & 64.0 & 26 & 12.3 & 50 & 23.7 & 507 & 80.09 \\
\hline 7 & $\begin{array}{l}\text { The stuff of the youth centers are not trained on } \\
\text { the works that they will do before transformation } \\
\text { or their upgrade functional which decrease their } \\
\text { performance. }\end{array}$ & 200 & 94.8 & -- & -- & 11 & 5.2 & 611 & 96.52 \\
\hline 8 & $\begin{array}{l}\text { A lot of splits and conflicts happens at the youth } \\
\text { centers because of making decisions that doesn't } \\
\text { enable the most of the board of directors and the } \\
\text { workers to understand the reason of it. }\end{array}$ & 150 & 71.1 & 50 & 23.7 & 11 & 5.2 & 561 & 88.62 \\
\hline 9 & $\begin{array}{l}\text { The information that reach to the most of the } \\
\text { workers at the youth centers doesn't be accurate or } \\
\text { new which cause a gap between it and the } \\
\text { community. }\end{array}$ & 140 & 66.4 & --- & --- & 71 & 33.6 & 491 & 77.57 \\
\hline 10 & $\begin{array}{l}\text { There is no trust at the youth centers because of } \\
\text { the lake of a certain mechanism that the board of } \\
\text { directors follow to recognize the activity inside } \\
\text { the youth centers. }\end{array}$ & 211 & 100 & -- & -- & -- & --- & 633 & 100 \\
\hline 11 & $\begin{array}{l}\text { There is no transparency values in working by the } \\
\text { team work spirit and the social justice which make } \\
\text { the splits inside the administrative. }\end{array}$ & 211 & 100 & --- & --- & --- & --- & 633 & 100 \\
\hline
\end{tabular}

The table (3) that specified of repetition, the percentage and the comparatively importance of the first axis phrases (the transparency at the youth centers as an entrance to the community development) clears that the comparatively importance of the phrases ranged between $(77.57 \%-100 \%)$ and the its highest was the phrases number $(10,11)$. 
Table (4) The percentage, the repetition, the comparatively importance and the weighting of the second axis phrases( accountability at the youth centers as an entrance to the community development $)(n=211)$

\begin{tabular}{|c|c|c|c|c|c|c|c|c|c|}
\hline \multirow{2}{*}{$\begin{array}{l}\text { The } \\
\text { term } \\
\text { num }\end{array}$} & \multirow[b]{2}{*}{ The second axis phrase } & \multicolumn{2}{|c|}{ Yes } & \multicolumn{2}{|c|}{ Partly } & \multicolumn{2}{|c|}{ No } & \multirow{2}{*}{$\begin{array}{l}\text { Weightin } \\
\mathrm{g}\end{array}$} & \multirow{2}{*}{$\begin{array}{c}\text { The } \\
\text { comparativel } \\
\text { y importance }\end{array}$} \\
\hline & & $\mathbf{K}$ & $\%$ & $\mathbf{K}$ & $\%$ & $\mathbf{K}$ & $\%$ & & \\
\hline 1 & $\begin{array}{c}\text { Un exposing the senior positions at the youth } \\
\text { centers to the legal accountability toward their } \\
\text { decisions and works helps to waste of public } \\
\text { money. }\end{array}$ & 145 & 68.7 & 9 & 4.3 & 57 & 27.0 & 510 & 80.57 \\
\hline 2 & $\begin{array}{l}\text { A lot of conflicts happens inside the youth centers } \\
\text { because the terms of references aren't appeared } \\
\text { and can't be determined. }\end{array}$ & 130 & 61.6 & 40 & 19.0 & 41 & 19.4 & 511 & 80.73 \\
\hline 3 & $\begin{array}{l}\text { The resistance of the senior positions' officials to } \\
\text { apply the accountability because of their belief } \\
\text { that it threats their positions and benefits } \\
\text { regardless the community benefit. }\end{array}$ & 155 & 73.5 & 5 & 2.4 & 51 & 24.2 & 526 & 83.10 \\
\hline 4 & $\begin{array}{l}\text { The lack of a mechanism to punish the individuals } \\
\text { inside the youth centers without discrimination } \\
\text { weakens the initiative. }\end{array}$ & 200 & 94.8 & 11 & 5.2 & -- & --- & 622 & 98.26 \\
\hline 5 & $\begin{array}{l}\text { Un applying a specific procedures to make the } \\
\text { violators' punishments suitable with the violation } \\
\text { size. }\end{array}$ & 130 & 61.6 & 48 & 22.7 & 33 & 15.6 & 519 & 81.99 \\
\hline 6 & $\begin{array}{l}\text { The supervision absence on the leaders' } \\
\text { performance at the youth centers causes absence } \\
\text { of the accountability ability which disable the } \\
\text { trust at the administrative workers. }\end{array}$ & 200 & 94.8 & --- & --- & 11 & 5.2 & 611 & 96.52 \\
\hline 7 & $\begin{array}{l}\text { Un applying of the punishments and the } \\
\text { administrative sanctions all over the senior } \\
\text { positions levels accurately encourage on violating } \\
\text { the legal and the regulations. }\end{array}$ & 200 & 94.8 & 5 & 2.4 & 6 & 2.8 & 616 & $\mathbf{9 7 . 3 1}$ \\
\hline 8 & $\begin{array}{l}\text { absence of a specific standards of reward and } \\
\text { punishment because of the unsuitability of the } \\
\text { individual responsibility size at the youth centers } \\
\text { with the authority that given to them. }\end{array}$ & 170 & 80.6 & 20 & 9.5 & 21 & 10.0 & 571 & 90.21 \\
\hline 9 & $\begin{array}{c}\text { The absence of the workers accountability } \\
\text { increases the ability of the administrative behavior } \\
\text { deviation so the devolution of power doesn't } \\
\text { happen. }\end{array}$ & 200 & 94.8 & 5 & 2.4 & 6 & 2.8 & 616 & 97.31 \\
\hline 10 & $\begin{array}{l}\text { Most of the workers gain a high annual } \\
\text { qualification report without a right evaluation of } \\
\text { the performance which leads to weak of the } \\
\text { reward mechanisms of the individuals inside the } \\
\text { youth centers. }\end{array}$ & 201 & 95.3 & 5 & 2.4 & 5 & 2.4 & 618 & 97.63 \\
\hline
\end{tabular}

The table (4) that specified of repetition, the percentage and the comparatively importance of the second axis phrases (the accountability at the youth centers as an entrance to the community development) clears that the opinion ranged between (80.57\%-98.26\%) and its highest was the phrase number (4).

Table (5)The percentage, the repetition, the comparatively importance and the weighting of the third axis phrases( participation at the youth centers as an entrance to the community development) $(n=211)$

\begin{tabular}{|c|c|c|c|c|c|c|c|c|c|}
\hline \multirow{2}{*}{$\begin{array}{l}\text { The } \\
\text { term } \\
\text { num }\end{array}$} & \multirow{2}{*}{ The third axis phrase } & \multicolumn{2}{|c|}{ Yes } & \multicolumn{2}{|c|}{ Partly } & \multicolumn{2}{|c|}{ No } & \multirow{2}{*}{$\begin{array}{l}\text { Weightin } \\
\mathrm{g}\end{array}$} & \multirow{2}{*}{$\begin{array}{c}\text { The } \\
\text { comparativel } \\
\text { y importance }\end{array}$} \\
\hline & & $\mathbf{K}$ & $\%$ & $\mathbf{K}$ & $\%$ & $\mathbf{K}$ & $\%$ & & \\
\hline 1 & $\begin{array}{l}\text { Isolating the board of directors members at the } \\
\text { youth centers in putting its policies which lead to } \\
\text { absence of the community participation aims. }\end{array}$ & 120 & 56.9 & 40 & 19.0 & 51 & 24.2 & 491 & 77.57 \\
\hline 2 & $\begin{array}{l}\text { Insulating the senior administrative at the youth } \\
\text { centers of making the decision doesn't motivate } \\
\text { the workers on the positive participation in }\end{array}$ & 140 & 66.4 & 30 & 14.2 & 41 & 19.4 & 521 & 82.31 \\
\hline
\end{tabular}




\begin{tabular}{|c|c|c|c|c|c|c|c|c|c|}
\hline & carrying on it. & & & & & & & & \\
\hline 3 & $\begin{array}{l}\text { Weaken of the participation methods leads to } \\
\text { isolate the benefiters away from the making the } \\
\text { decision process at the youth centers. }\end{array}$ & 130 & 61.6 & 40 & 19.0 & 41 & 19.4 & 511 & 80.73 \\
\hline 4 & $\begin{array}{l}\text { The strategic planning at the youth centers doesn't } \\
\text { include their participation at solving the } \\
\text { community problems. }\end{array}$ & 130 & 61.6 & 35 & 21.3 & 46 & 17.1 & 506 & 79.94 \\
\hline 5 & $\begin{array}{l}\text { Non-contributing the workers in the specific } \\
\text { activities leads to absence of trust between the } \\
\text { administrative and the workers. }\end{array}$ & 188 & 89.1 & 3 & 1.4 & 20 & 9.5 & 590 & 93.21 \\
\hline 6 & $\begin{array}{l}\text { Not guarantee freedom of speech alienating the } \\
\text { workers at the youth centers away from } \\
\text { participating in putting the instructions and the } \\
\text { regulations resulting the neglect of the } \\
\text { instructions. }\end{array}$ & 200 & 94.8 & 1 & 0.5 & 10 & 4.7 & 612 & 98.10 \\
\hline 7 & $\begin{array}{l}\text { Putting a clear policies leads to help the benefit } \\
\text { audience on dealing as a effective partner. }\end{array}$ & 130 & 61.6 & 41 & 19.4 & 40 & 19.0 & 512 & 80.88 \\
\hline 8 & $\begin{array}{r}\text { isolating of the community to evaluate the } \\
\text { presented services leads to inactivity and } \\
\text { inefficiency of the performance. }\end{array}$ & 150 & 71.1 & 26 & 12.3 & 35 & 16.6 & 537 & 84.83 \\
\hline 9 & $\begin{array}{l}\text { Unexciting of an administrative system inside the } \\
\text { youth centers allows giving the chance to all the } \\
\text { parties to participate their thoughts and their } \\
\text { creative efforts to help the community. }\end{array}$ & 135 & 64.0 & 20 & 9.5 & 56 & 26.5 & 501 & 97.15 \\
\hline
\end{tabular}

The table (5) that specified of repetition, the percentage and the comparatively importance of the third axis phrases (the participation at the youth centers as an entrance to the community development) clears that the opinion ranged between $(77.57 \%-98.10$ )and its highest was the phrase number (6).

Table (6) The percentage, the repetition, the comparatively importance and the weighting of the fourth axis phrases( rule of law at the youth centers as an entrance to the community development $)(n=211)$

\begin{tabular}{|c|c|c|c|c|c|c|c|c|c|}
\hline \multirow{2}{*}{$\begin{array}{l}\text { The } \\
\text { term } \\
\text { num }\end{array}$} & \multirow{2}{*}{ The fourth axis phrase } & \multicolumn{2}{|c|}{ Yes } & \multicolumn{2}{|c|}{ Partly } & \multicolumn{2}{|c|}{ No } & \multirow{2}{*}{$\begin{array}{l}\text { Weightin } \\
\mathrm{g}\end{array}$} & \multirow{2}{*}{$\begin{array}{c}\text { The } \\
\text { comparativel } \\
\text { y importance }\end{array}$} \\
\hline & & $\mathbf{K}$ & $\%$ & $\mathbf{K}$ & $\%$ & $\mathbf{K}$ & $\%$ & & \\
\hline 1 & $\begin{array}{r}\text { Weaken of the regulations and systems leads to } \\
\text { increase the administrative corruption at the youth } \\
\text { centers. }\end{array}$ & 200 & 94.8 & 11 & 5.2 & -- & ---- & 622 & 98.26 \\
\hline 2 & $\begin{array}{l}\text { Not spreading the law in a way that guarantee to } \\
\text { reach into the individuals' knowledge increase the } \\
\text { legal disputes. }\end{array}$ & 211 & ---- & -- & ---- & -- & --- & 633 & 100 \\
\hline 3 & $\begin{array}{l}\text { Injustice in applying the legal roles leads to } \\
\text { inequality in using the reward and punishment } \\
\text { mechanisms between the workers at the youth } \\
\text { centers. }\end{array}$ & 209 & 99.1 & 2 & 0.9 & --- & --- & 631 & 99.68 \\
\hline 4 & $\begin{array}{l}\text { Un existing of a conflict resolution mechanisms } \\
\text { increasing the conflict period between the } \\
\text { benefiters and the youth centers. }\end{array}$ & 207 & 98.1 & 4 & 1.9 & --- & --- & 629 & 99.37 \\
\hline 5 & $\begin{array}{l}\text { The absence of one framework and reference to } \\
\text { commitment that applied on all parties affect } \\
\text { negatively on the community development. }\end{array}$ & 120 & 56.9 & 30 & 14.2 & 41 & 28.9 & 461 & 72.83 \\
\hline 6 & $\begin{array}{r}\text { Non existing of the systems, the regulations and } \\
\text { the security procedures to encourage and protect } \\
\text { persons who contribute in reveling the } \\
\text { administrative corruption. }\end{array}$ & 135 & 64.0 & 35 & 16.6 & 41 & 19.4 & 516 & 81.52 \\
\hline 7 & $\begin{array}{l}\text { Delaying the executive and the judicial systems to } \\
\text { proceed a trial to the administrative corruption } \\
\text { accused at the youth centers. }\end{array}$ & 138 & 65.4 & 10 & 4.7 & 63 & 29.9 & 497 & 78.51 \\
\hline 8 & $\begin{array}{c}\text { Dropping of the observation system quality level } \\
\text { inside the youth centers in doing its role because } \\
\text { taking away their enough authority and the lack of } \\
\text { its human and financial possibilities. }\end{array}$ & 205 & 97.2 & 2 & 0.9 & 4 & 1.9 & 623 & 98.42 \\
\hline
\end{tabular}


The table (6) that specified of repetition, the percentage and the comparatively importance of the fourth axis phrases (the rule of the law at the youth centers as an entrance to the community development) clears that the opinion ranged between $(72.83 \%-100 \%$ ) and its highest was the phrase number (2).

\section{Discussing the results:}

Through the exposed results at the table (3) that specified of the repetition, the percentage and the comparatively importance of the first axis phrases ( the transparency at the youth centers as an entrance to the community development) it clears the existence of a huge shortage in providing, accurate and trading the information that the administrative decision making process based on inside the youth centers, also the existence of a similar shortage in renewing mechanisms that enable the benefiters of the youth centers activities to express their suggestions and ambitions in the youth centers. besides, the process of employing process at the youth centers and promoting them depends on the principle of seniority not the quality with the absence of training during serving which leads to make an administrative mistakes during the management process and not taking the in mind the benefiters opinions to meet their needs and lack the clarity of vision during making the decisions because of the information shortage and misunderstanding to the motives behind making a certain decisions because the weaken of the connection channels between the administrative levels and each other and between the centers and the benefiters.

Wellens \& Jegers (2014) point that the transparency as one of the governance principles has been built from the beginning on the disclosure of information in an accurately, clearly and rightly shape and including a time frame that suits the making decision process and that any weakness happened to the disclosure of information process and trading it necessary leads to internal and external conflicts that reflecting negatively on the quality of the decision made inside the sports institution and weaken the trust of the benefiters.(14)

Also Andreff (2015) and Geeraert et al agree with the importance of the transparency as one of the pillars that support making the right decision inside the sports institutions as it provides the obvious basis to make the decision and understanding the reason of making it by the workers and the benefiters, also it clears accurately the duties and the missions of all of the administrative responsible toward activating this decision and the size of benefit that the benefiters gain which decrease the chance of starting internal and external conflicts. (6)(7)

Also Berbes(2016) and Ezzaldean(1996) see that the absolute depending on the seniority not the quality in filling the leadership positions inside the sports institutions and the absence of the effective role of the training process during the service on the new missions before doing it leads to a status of the administrative weakness while carrying out the decisions also it shows the conflict of interest between the administrative levels which leads finally of the institution to fail in achieving its goal.(3)(5)

The researcher sees that the clear weakness in applying the transparency principle at the youth centers in Egypt reflects negatively on these vital institutions and leads it to fail in achieving its aims according to the message and vision prepared to it, so the researcher sees the necessity of reviewing the accuracy, trading and disclosure mechanisms that related with the information inside the youth centers and the necessity of developing a new mechanisms that enable the local community that benefit from the activities of these centers to express their opinions, ambitious and hopes about these center. besides there is an urgent need to review the promoting and employing mechanisms inside the youth centers and provide what is needed of training the jobs fillers inside the youth centers before filling it.

From the represented results of table (4) that specified of repetition, the percentage and the comparatively importance of the second axis phrases (the accountability at the youth centers as an entrance to the community development) clears that there is a clear and intense shortage in applying the accountability principle as one of the governance principle inside the youth 
centers in The Arab Republic of Egypt as the results point to neglect of applying that principle on the senior leadership position either because of resisting the senior leadership positions to this to maintain their prestige or the absence of the legislation and regulations that guarantee to apply this principle equally between all inside the center regardless of their position. also the weakness and absence of the internal censorship on the center's work leads to weaken the workers and benefiters' trust both in the quality of the administrative system of the center and its capability of achieving the public goals of the center. and the absence of accountability leads necessary to appear an administrative deviations that disable the power trading process also it limits the performance evaluating process to formality that leads workers to gain a high annual reports regardless the actual performance level.

Rossi et al (2015) ensure that the process of accountability is the basic guarantee of nonconflict of competencies and doing every individual his responsibilities toward achieving the institution's goals according to his administrative level, also it is an important pillar of the general performance evaluating process of the institution pillars which according to it the promoting and ensuring of the institution's work process done.(11)

also Weatherill (2014) sees that accountability and applying the principles of reward and punishment fairly and non-discriminatory on all of the workers of the institution is the guarantee the it presenting to the local community to ensure seeking toward achieving its aims and displaying a high quality service to the benefiters.(13)

the researcher sees that the absence of the accountability principle and the inequality in applying the punishment and reward principle is the door that leaking the administrative corruption into the youth centers as the absence of the accountability necessary means not clarified each one responsibility about his behaviors and decisions and regarding of his mistakes opens the door in front of repeating the mistakes and increasing it in a way that leads at the end to disable the youth centers from doing its role in the community development.

From the results that exposed from the table (5) that specified of repetition, the percentage and the comparatively importance of the third axis phrases (the participation at the youth centers as an entrance to the community development) clears that the high administrative levels at the youth centers are totally isolating with the process of making the decision without sharing the local community or the lower administrative levels in this process which leads to a huge shortage in the role that the youth centers play in the community development.

Mcnamee \& Fleming (2007) ensure that expulsing the lower administrative levels to participate in the process of making the decision leads to the lack in trust about the suitability and the rightness of these decisions which leads to decrease in the performance level inside the institution as a direct result to the trust decreasing and the increasing feel of the administrative marginalization by the higher administrative levels.(9)

Also O'boyle \& shilbury (2016) see that absence of the community participation in the making decision process inside the sports institutions probably leads to determine aims and draw policies that are far away from the benefiters' ambitious and needs which leads finally to disable the institution to achieve its actual goals.

also the participation of the benefiters at the making decision process makes them feel like owning the right to guide the institution policies toward meeting their actual needs without feeling marginalization or exclude away from this pivotal process.(10)

The researcher sees that the activated participation from all of the administrative level's side inside the youth centers is the pillar in rising the workers' qualification and achieving the highest performance rate that possible due to increase their feelings of responsibility toward the decisions made and the necessity of carrying it out perfectly, also the participation of the benefiters at the process of making the decision guarantee to taking their ambitious and need 
in consider by the institution to maintain it as the youth centers are a service institution that basically and directly aims to achieve the continuous community development inside the local community.

Also it clears from the presented results from the table (6) that specified of repetition, the percentage and the comparatively importance of the fourth axis phrases (the rule of the law at the youth centers as an entrance to the community development) that there is a shortage at number of the legislative and legal aspects that related with the administrative performance of the youth centers such as the weaken of the administrative regulation that organized the work and not spreading this regulations and laws including the workers knowledge directly of it and the injustice in applying the law roles and therefore the inequality in using the reward and punishment mechanisms between the workers. also the results pointing to the absence of the internal conflict solving mechanisms which increase the depth of these conflicts while it starts. moreover it clears that slowing in judgment the administrative corruption accused leads to outbreak the phenomenon inside the youth centers also the internal censorship systems at these centers doesn't have the enough authority to stop the administrative corruption that resulted from the obvious legislative weakness.

Geeraert et al (2014) and Weatherill (2014) see that the absence of the legal legislation or its weakness spreading the administrative corruption phenomenon as a direct result of the absence of intensive punishment that guarantee limiting the administrative corruption phenomenon inside sports institutions, and that the legislation environment that supports the development is the one that enable the sports institutions to do its developmental responsibilities and achieving its goals according to an active and clarity institutional strategies.(7)(13)

Also Soliman (2006), Shosha(2009), Aloteby(2013) ensuring that the full power internal censorship is one of the most successful methods to face the administrative and financial corruption inside the sports institutions as the absence of the internal observation or its weakness and incomplete its powers leads to the administrative system shortage to a clear mechanism to internal reviewing and evaluating and facing the administrative corruption cases early and before increasing it.(2)(4)(1)

And the researcher sees that slowing at the judgmental procedures and executing the punishment provisions at the administrative corruption cases is one of the most important reasons behind the phenomenon spreading at the administrative system in the whole country and inside the youth centers privately also the injustice in taking the punishment procedures toward the corruptors leads to doubts between the worker and the center management which weaken the workers performance and make them lazier and more corrupted because of their feeling of the lack of direct legal responsibility they may expose to.

Finally, the obvious shortage in applying the governance principles inside the youth centers disable these centers to play its vital and sensitive role in the community development. and this shortage due to the non-transparency, unaccountability and isolation inside the administrative system of the center besides the weakness of the rolling legislation aspects to these centers work.

\section{The extractions:}

In the light of this study and its questions, procedures and conclusions we extract the following:

1. There is a clear shortage in applying the transparency principle inside the youth centers in The Arab Republic of Egypt and this shows from the following:

- There is a big shortage in the range of availability, accuracy and currency of the information that the administrative decision making process based on inside the youth centers. 
- The existence of shortage in developing a new mechanisms that enable the youth centers benefiters of expressing their suggestions and ambitious of the youth centers.

- The process of employment in the youth centers and promoting them on the seniority principle not he quality with the absence of the training during the service.

2- There is an intense and clear shortage in applying the accountability principle as one of the governance principle inside the youth centers at the Arab Republic of Egypt and this clears from the following:

- Not Applying the accountability on the senior leadership positions because of the resistance of the senior administrative levels to this to keep their prestige.

- The absence of regulations and legislations that guarantee applying the accountability principle equally between all inside the center regardless what position he fills.

- The weaken and absence of the internal censorship on the centers work leads to weaken the workers and benefiters' trust both at the quality range of the administrative system work and its capability of achieving the centers' public aims.

- The absence of the accountability necessary leads to appear an administrative deviation that disable the power trading process, also it shorting the performance evaluation process on the form aspect that leads to gain a workers' high annual reports regardless of the performance actual level.

3- There is an obvious lack in applying the participation principle inside the youth centers as the senior administrative levels at the youth centers isolating completely with the making decisions process without sharing the local community or the lower administrative levels in this process which leads to the existence of a huge lack in the role that the youth centers play at the community development.

4- There is a shortage at number of the legislation and legal aspects that related with the administrative performance of the youth centers that represented in :

- Weaken of the administrative regulations that organized the work and not spreading these regulations and laws guarantying knowing the workers of it.

- Injustice in applying the legal roles and therefore the inequality in using the reward and punishment mechanisms between the workers.

- The absence of the internal conflict solutions mechanisms which increase the deep of this conflicts while it starts.

- Slowing to trial the administrative corruption accused leads to outbreak the phenomenon inside the youth centers.

- The internal control systems doesn't have the enough authority to stop the administrative corruption that resulted from the clear legislation weakness.

\section{The recommendations:}

In the light of the previous extractions the researcher recommending the following:

- The necessity of reconsidering the internal and external information trading at

the youth centers in the Arab Republic of Egypt including the effective application of the transparency principle.

- Obligating the youth centers to spread the closing account and the annual budget items in a way that enable the internal and external sides to recognize the commitment range of the centers' administrations with the budget items that planned by the board of directors and the general assembly. 
- Developing mechanisms to recognize the local community needs to insert them including the annual plan of the center's work.

- Applying a comprehensive training plane to the center's workers that includes preparing them to their missions.

- Applying the quality system as an alternative to the seniority system while promoting to fulfill the senior leadership jobs inside the youth centers.

- The necessity of applying the accountability principle on all of the administrative levels at the center regardless of its position.

- The necessity of equality in applying the reward and punishment to all without prejudice to a certain administrative level.

- The necessity to reconsider the administrative performance evaluation systems that the make it not limited to the formal aspects.

- Relating the administrative promotions with carrying out the missions as a method of applying the accountability principle.

- The necessity to participate all of the administrative levels at the decision making process and not limiting the process on the senior administrative levels.

- The necessity of sharing the local community in the decision making process.

- The necessity of making the annual plans and the aims according to the local community needs that benefit of the service.

- The necessity of reviewing the regulations, the legislations and the roles that organize the work inside the youth centers.

- The necessity of accelerating the suing procedures at the administrative corruption cases to punish the wrong.

- The necessity of taking complete executive procedures toward applying the governance principles inside the youth centers in The Arab Republic of Egypt.

\section{The references list:}

The Arabic references:

1- Aloteby, Badr Aied (2013): " The effect of the social and administrative corruption on the sports institutions", the European journal of the sports science technology, the second edition, Kuwait.

2- Soliman, Mohamed Hassan(2006): " The companies governance and treatment of the administrative and financial corruption", The university house, Alexandria, p9.

3-Shiref , Berbies (2016): "The role of governance mechanisms to limit the financial and administrative corruption in the sports institutions , the business conflicts journal,

Algeria University, p3.

4- Shosha, Mhamed (2009): "A suggested image to the administrative policies of the judgments comities in the hand ball Egyptian union at the light of the governance principle", unpublished master thesis Faculty of physical education, Asiot university, p112.

5- Ezz aldean, Naeam(1996): "Evaluating the sports activity at the youth centers in Algiza governorate , unpublished master thesis, faculty of physical education for boys,

Helwan university, Cairo, p124. 


\section{The foreign references:}

1. Andreff, W. (2015). Governance of Professional Team Sports Clubs: Agency Problems and Soft Budget Constraints. Disequilibrium Sports Economics, Elgar: London, 175-228.

2. Geeraert, A., Alm, J., \& Groll, M. (2014). Good governance in international sport organizations: an analysis of the 35 Olympic sport governing bodies. International journal of sport policy and politics, 6(3), 281-306.

3. Huang, F., \& Hong, F. (2015). Globalization and the Governance of Chinese Sports: The Case of Professional Basketball. The International Journal of the History of Sport, 32(8), 1030-1043.

4. McNamee, M. J., \& Fleming, S. (2007). Ethics audits and corporate governance: The case of public sector sports organizations. Journal of Business Ethics, 73(4), 425-437.

5. O’Boyle, I., \& Shilbury, D. (2016). Exploring issues of trust in collaborative sport governance. Journal of Sport Management, 30(1), 52-69.

6. Rossi, G., Leardini, C., Moggi, S., \& Campedelli, B. (2015). Towards community engagement in the governance of non-profit organizations. Voluntary Sector Review, 6(1), 21-39.

7. van den Hurk, M., \& Verhoest, K. (2015). The governance of public-private partnerships in sports infrastructure: Interfering complexities in Belgium. International Journal of Project Management, 33(1), 201-211.

8. Weatherill, S. (2014). The influence of EU law on sports governance. In European Sports Law (pp. 443-469). TMC Asser Press.

9. Wellens, L., \& Jegers, M. (2014). Effective governance in nonprofit organizations: A literature based multiple stakeholder approach. European Management Journal, 32(2), 223-243. 